\title{
Wardium mackoifusa sp. n. (Cestoda, Cyclophyllidea), a parasite of the little gull (Larus minutus Pall.) from Ukraine
}

\author{
O. B. GREBEN*, V. V. KORNYUSHIN
}

\author{
Schmalhausen Institute of Zoology NAS of Ukraine, 15, Khmelnitsky Str., Kyiv, 01601 Ukraine, \\ *E-mail: oksana-greben@yandex.ru
}

\begin{abstract}
Summary
The new cyclophyllidian species Wardium mackoifusa sp. n. (Aploparksidae Mayhew 1925), in the little gull (Larus minutus Pall.) from Ukraine is described. The species is characterized by 10 aploparaksoid hooks, each 13-15 $\mu \mathrm{m}$ long. It noticeably differs from all of the species of this genus by the shape and the armament of the cirrus and the presence of polar delicate filaments on the embryophore of eggs.
\end{abstract}

Keywords: Larus minutus Pall.; Wardium mackoifusa sp. n.; Cestoda; Aploparaksidae; Ukraine

\section{Introduction}

Two aploparaksoid cestode species were previously found in a little gull (Larus minutus Pall.) in Ukraine: Hymenolepis (s.1.) fusus (Krabbe, 1869) Bondarenko, Kontrimavichus, 2004 (Syn. Wardium fusa (Krabbe, 1869) Spassky, 1961) and Wardium spasskii Shigin, 1961 (Smogorjewskaja, 1976; Smogorjewskaja et al., 1978; Grushchinskaja, 1978; Ryzhikov et all., 1985). The first is a parasite of various gulls, the second - a parasite of the little gull and sometime of common tern (Sterna hirundo L.). In 1964 Macko, when describing cestodes of gulls in Slovakia, presented also the figure of «atypical» cirrus of $W$. fusa from the little gull (Macko, 1964). Bondarenko and Pyatkavichute (1998), Bondarenko and Kontrimavichus (2004) showed that $H$. (s.1.) fusus is a parasite of various gulls (Family Laridae Rafinesque, 1815), however the little gull was not its host.

We re-examined cestode specimens from the little gull, which was collected on the territory of Ukraine and was previously identified as $H$. (s.1.) fusus. We found specimens of the genus Wardium (Mayhew, 1925) differing morphologically from both $H$. (s.1.)fusus and W. spasskii as well as from other known specimens of this genus. The shape and armament of the cirrus of the specimens of the little gull from Ukraine appeared to be identical to the shape and armament of «atypical» cirrus W. fusa of the little gull (Macko, 1964) from Slovakia. We consider them as belonging to a new species, Wardium mackoifusa sp. n. which is described herein. A new species is belonging to the genus Wardium on the presence 10 aploparaksoid-type hooks and three testes.

\section{Material and methods}

All material was collected from little gull, seven birds examined by Smogorzhevskaya on the Sasyk Lake (Crimea) in May of 1955, seventeen birds examined by Kornyushin in district Potiyivka (Black Sea Biosphere Reserve, Kherson Oblast) in May and August of 1964, sixteen birds examined by Grushchinskaja on the Kremenchug reservoir (Poltava Oblast) in July 1974. The tapeworms were fixed in $70 \%$ alcohol, stained with Mayer's haematoxylin and acetocarmin, dehydrated in an ascending alcohol series, cleared in clove oil and mounted in Canada balsam. Morphology of the scolex and cirrus was studied in Berlese's medium.

The new species was found in all three localities. Prevalence and intensity of the little gull infection by $W$. mackoifusa sp. n. was 5/7, $1-37$ specimens on the Sasyk Lake; $64.7 \%, 1-38$ specimens in Potiyivka and $43.8 \%, 1-22$ specimens on Kremenchug reservoir.

All measurements are in micrometers unless otherwise stated. In the description of W. mackoifusa sp. n., the measurements given before the parenthesis are those of the holotype.

\section{Results}

Order Cyclophyllidea van Beneden in Braun, 1900

Superfamily Hymenolepidoidea Spassky, 1949

Family Aploparaksidae Mayhew, 1925 


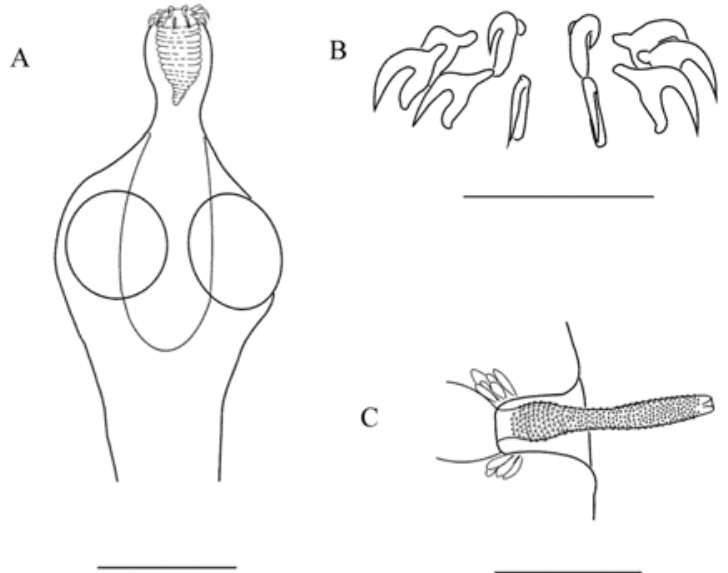

Fig. 1. Wardium mackoifusa sp. n. Holotype: A - scolex; B - crown of rostellar hooks; $\mathrm{C}$ - cirrus. Scale bars: A $-100 \mu \mathrm{m} ; \mathrm{B}, \mathrm{C}-20 \mu \mathrm{m}$.

\section{Wardium mackoifusa sp. $\mathbf{n}$.}

Type host: little gull, Larus minutus Pall., (Aves: Laridae). Site: Small intestine.

Type locality: Ukraine, Kherson Oblast, BSBR, district Potiyivka $\left(46^{\circ} 07^{\prime} \mathrm{N} ; 32^{\circ} 17^{\prime} \mathrm{E}\right)$.

Other localities: Ukraine (Crimea, Sasyk Lake; Poltava Oblast, Kremenchug reservoir), Slovakia.

Type specimens: Holotype $(\mathrm{CH} \mathrm{34)} \mathrm{from} \mathrm{L.} \mathrm{minutus,} \mathrm{№}$ 303 - 5 a, 28.05.1964; paratypes (CP 34.1 - CP 34.4), of the same host (4 specimens), (CP 34.5 - CP 34.7) from $L$. minutus № 320 - 15, 30.05.1964 (3 specimens), (CP 34.8) from L. minutus № 317 - 14, 30.05.1964 (1 specimen).

The type material is stored in the helminthological collection of the Institute of Zoology of the National Academy of Sciences of Ukraine, Kyiv.

Etymology: The species name is given in honour to the prominent cestodologist Dr. S. Macko who first recorded the atypical form of the cirrus of $W$. fusa from the little gull.

Description of the type-specimens (Fig. 1, 2, 3, 4).

Length of immature specimen $90 \mathrm{~mm}$ (holotype), total length of mature specimens - up to $108 \mathrm{~mm}$. Maximum width at level of gravid proglottids $1.3 \mathrm{~mm}$. Scolex 240 $(170-200)$ in length and $145(130-150)$ in diameter at level of suckers. Suckers oval $60-70 \times 70-80(50-70 \times$ 70 - 80). Rostellar sheath sac-like $143 \times 70(130-140 \times$ 45 - 55), crossing posterior suckers margin. Small muscular rostellum $50(45-70)$ long and $40(30-40)$ in diameter at level of hooks. Rostellum armed by 10 aploparaksoid hooks with noticeable handle (Fig 5. A). Total length of hooks $13-15(13-15)$, depending on position in slide. Length of blade $6.3-7(6.3-7.5)$; length of base with guard $10(8-11)$; length of guard $4.5-5(5-7)$; length of handle $3.8-4(3.8-4.5)$. Neck width is $80(70-80)$ wide. Strobila delicate. Genital pores unilateral opening in anterior third of lateral proglottid margin. Longitudinal musculature consisting of 4 large bundles on each (dorsal and ventral) surface of strobila and of numerous small bundles. Osmoregulatory canals 2 pairs; transverse anastomoses not observed. Diameter of ventral osmoregulatory canals 30 , of dorsal canals $5-7$.
Development of proglottids protandrous. Male system forms and develops earlier then female. Three testes rounded $35-55(20-50)$ in diameter or slightly oval $30-$ $50 \times 40-55$. In male proglottids, they are situated behind the cirrus-sac in a transverse row in median field of the proglottid, between the osmoregulatory canals. Cirrus-sac long and narrow, $160-210 \times 22-30(130-220 \times 20-$ 25). In male proglottids, it crosses the median line of the proglottid and reaches aporal osmoregulatory canals. Cirrus-sac becomes relatively shorter with the development of the strobila. In young female proglottids, it crosses median line of the proglottid, but does not reach aporal osmoregulatory canals. In gravid proglottids, cirrus-sac is relatively short, not crossing the middle of proglottide. Internal seminal vesicle occupies almost the whole space of the cirrus-sac. External seminal vesicle oval $60-100 \times 45-$ $70(40-105 \times 30-80)$, or rounded $30-60$, in diameter. It is situated near the antiporal region of the cirrus-sac or at some distance from cirrus-sac, leaning on its dorsal side.

Fully-evaginated cirri were absent in the studied specimens (Fig. 5. B). Cirrus length of holotype 38.8. Maximum cirrus length 60 (paratype). Its form is approximately spindleshaped. Basal part of cirrus $10-13(8-13)$ in length and 6 $-7(5-10)$ in diameter, thickly covered with small spines. This part of cirrus is situated within the genital atrium. Median part of cirrus narrow $20-23(15-25)$ in length and $5-5.5$ in diameter, covered with smaller spines. Then follows a dilation about 7 in diameter and then distal part.
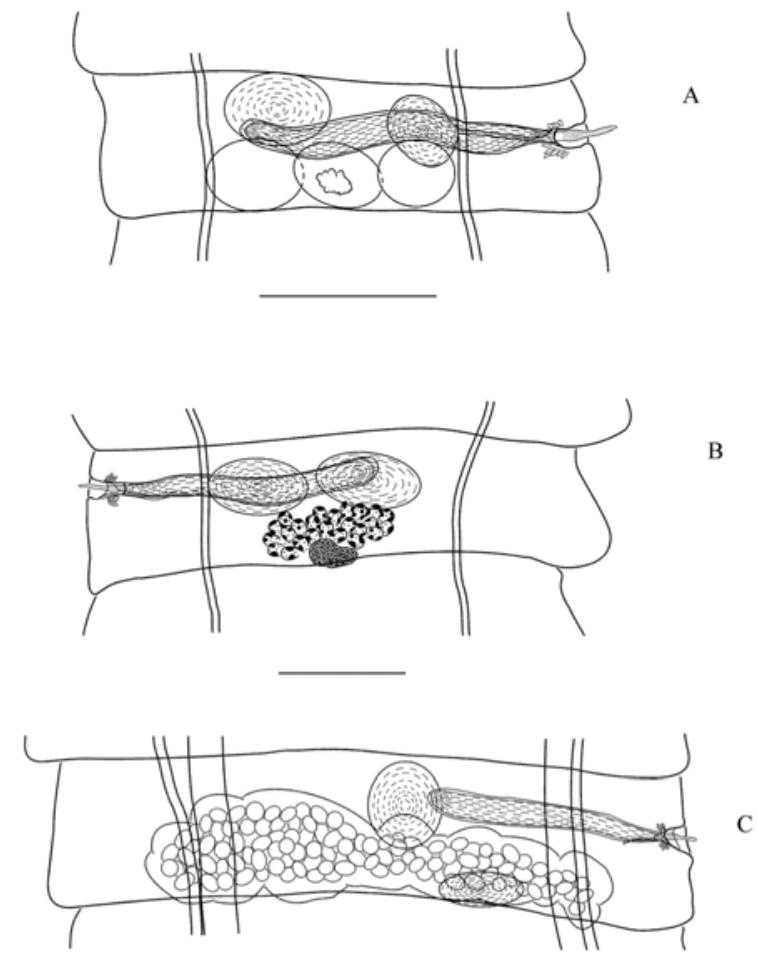

Fig. 2. Proglottids of Wardium mackoifusa sp. n. (Holotype): A - male proglottid; B - female proglottid; $\mathrm{C}$ - gravid proglottid. Scale bar $100 \mu \mathrm{m}$. 

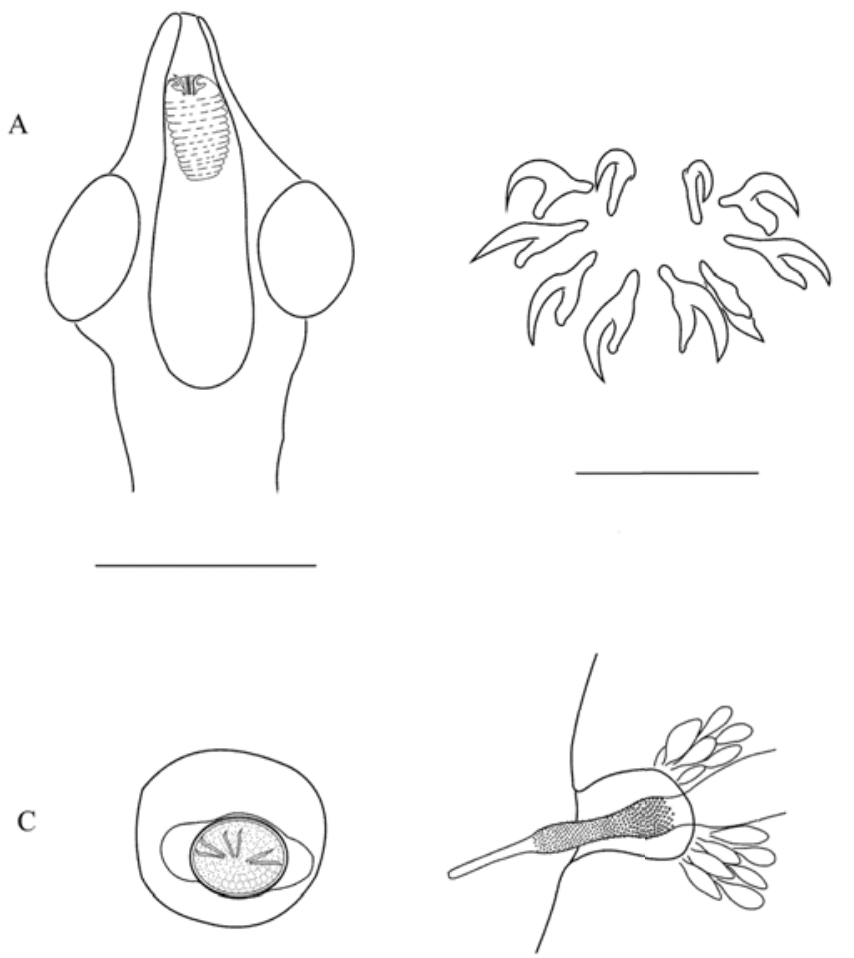

D

Fig. 3. Wardium mackoifusa sp. n. Paratype: A - scolex; B - crown of rostellar hooks; C - egg; D - cirrus. Scale bars: A - 100 um: B. D - 20 um: C -50 um.

Distal part of the cirrus is pipette-like, $2.5(2.5-3)$ in diameter unarmed. Maximum length of cirrus distal part in the paratype is about 22 .

Genital atrium simple, feebly muscular. Sometimes it tightens, forming tube. Clumps of glandular cells near opening of cirrus-sac usually present.

Female genitalia develop from rounded primordium in the proglottids with well-developed testes. The primordium is situated at posterior margin of proglottid in the middle. Developed ovary knobbed or weakly lobed, situated in postero-central part of median field. It has 3 implicit lobes. Testes in these proglottids are inconspicuous. Maximum length of ovary 140 (210). Vitellarium oval, $35-40 \times 25-$ $35(25-70 \times 15-50)$, rarely of irregular shape. It is situated posteriorly and ventrally to the centre of ovary. Vagina opens into genital atrium posteriorly or ventrally to male pore. Copulatory part of vagina funnel-shaped, $10-$ $15(10-17)$ in diameter. Conductive part of vagina tubular, narrow 2.5 in diameter. Its length varies. In some proglottids oval seminal receptacle, $55-135 \times 50-75(35-$ $110 \times 35-60)$ is seen. Seminal receptacle is situated under the cirrus-sac or shifts to aporal end of the cirrus-sac, towards antiporal osmoregulatory canals. Seminal receptacle can remain in gravid proglottids.

Saccular uterus starting its development in place of female gonads (Fig. 5. C). It grows in width and enters lateral fields outside osmoregulatory canals, thus filling entire proglottid. Mature eggs spherical 60-80 in diameter, embryophore oval $55-70 \times 35-40$ (observed in paratypes). Oncosphere $35-40 \times 25-28$. Embryonic hooks $13-15$.
Minor delicate filaments are visible at poles of egg embryophore after maceration of fixed material in water during a day (Fig. 5. D).

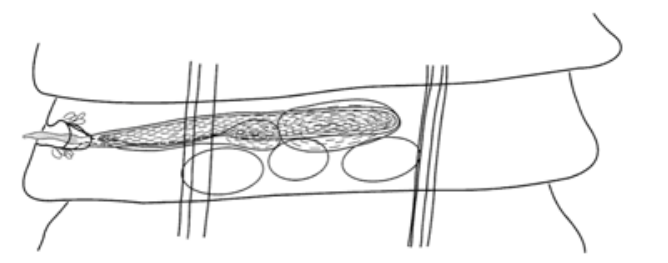

A
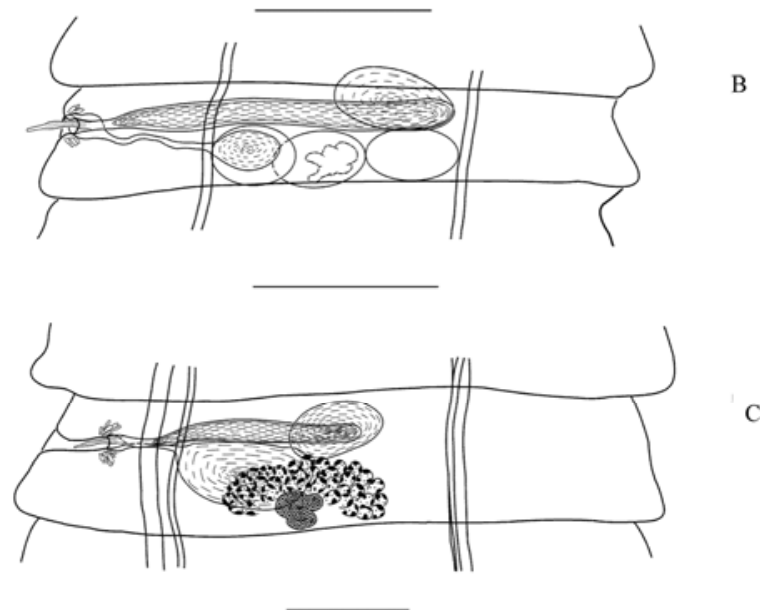

Fig. 4. Proglottids of Wardium mackoifusa sp. n. (Paratype): A - male proglottid; $\mathrm{B}$ - proglottid with female anlage; $\mathrm{C}$ - female proglottid. Scale bar $100 \mu \mathrm{m}$. 


\section{Taxonomic remarks}

By the length of relatively small rostellar hooks W. mackoifusa sp. $\mathrm{n}$. is similar to the following members of the genus Wardium: Wardium cervotestis (Ahern et Schmidt, 1976) Bondarenko, 1999, Wardium collariella (Coil, 1956) Bondarenko et Kontrimavichus, 2006, Wardium paraclavicirrus Oschmarin, 1963.

Wardium mackoifusa sp. n. differs from W. cervotestis (hooks 13 - 16 long), a parasite of Recurvirostra americana, by the shape of rostellar hooks, relatively smaller cirrus-sac, the cirrus shape and morphology of eggs. Hooks of $W$. cervotestis have thinner blade. Cirrus sac of $W$. cervotestis $95-205 \times 16-37$ in size, reaches only poral test, cirrus sac of W. mackoifusa sp. n. $(60-120 \times 20$ - 50), crosses the median field of proglottid. Cirrus of $W$. cervotestis is cigar-shaped. Its median part is slightly widened, armed with small spines. Unarmed distal part of cirrus gradually tapers. Cirrus of $W$. mackoifusa sp. n. has two enlargements with different spines. Oncosphere in eggs of $W$. cervotestis is oriented along major axis of embryophore. Oncosphere in eggs of W. mackoifusa sp. n. is ordinarily oriented (Ahern \& Schmidt, 1976; Bondarenko \& Kontrimavichus, 2006).

Wardium collariella (hooks 15 - 16 long) had been described from Charadrius collaris in Mexico and has not been reported thereafter. Wardium mackoifusa sp. n. differs from $W$. collariella by the shape of rostellar hooks, size and armament of cirrus, absence of testes in proglottis with mature female genitalia. Rostellar hook of W. mackoi-

A

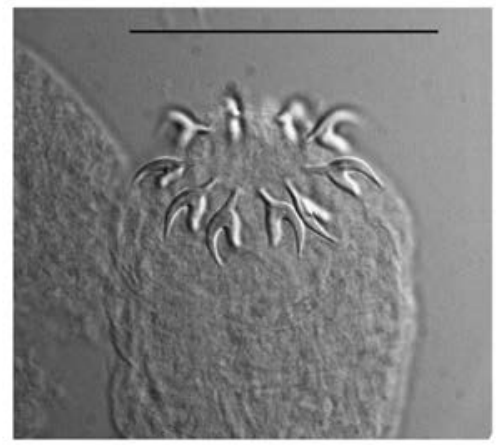

$\mathrm{C}$

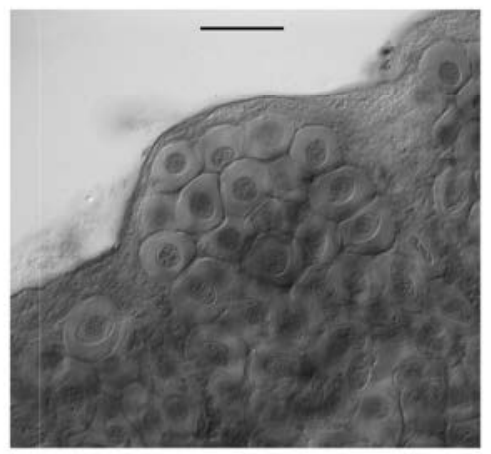

fusa sp. n. has a handle and the hook handle of $W$. collariella is not noticeable. Wardium mackoifusa sp. n. has shorter cirrus (cirrus length 32.5 - 50 vs 143 in $W$. collariella) with spines on it (Coil, 1956; Bondarenko \& Kontrimavichus, 2006).

Wardium paraclavicirrus (hooks 16 long), specific parasite of snipes (Gallinago spp.), differs from Wardium mackoifusa sp. n. by the shape of rostellar hooks, size, shape and armament of cirrus. Hook blade of $W$. paraclavicirrus is longer. Cirrus of $W$. paraclavicirrus is large, 240 - 260 long, with maximum width of 57 in its distal part, leaf-shaped, armed by small homogeneous spines, whereas the cirrus of $W$. mackoifusa sp. n. is armed by heterogeneous spines. It has massive swelling in median part (Oschmarin, 1963; Bondarenko \& Kontrimavichus, 2006).

There are another hymenolepidid cestodes with aploparaksoid-type hooks and three testes in a proglottid, that are parasites of different gulls. These are the members of the genus Branchiopodataenia Bondarenko et Kontrimavichus, 2004, as well as the some species of the genus Hymenolepis s.1. By the length of rostellar hooks W. mackoifusa sp. n. is similar to the following three species of genus Branchiopodataenia: Branchiopodataenia arctowskii (Jarecka et Ostas, 1984) Bondarenko et Kontrimavichus, 2004 (hooks 14 - 20 long), Branchiopodataenia haldemani (Schiller, 1951) Bondarenko et Kontrimavichus, 2004 (hooks 12 - 14 long) and Branchiopodataenia pacifica (Spassky et Jurpalova, 1968) Bonda-

\section{B}

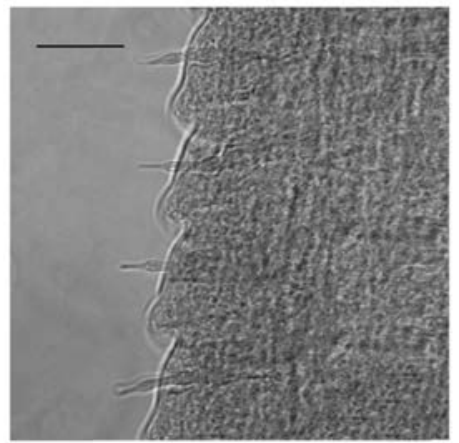

D

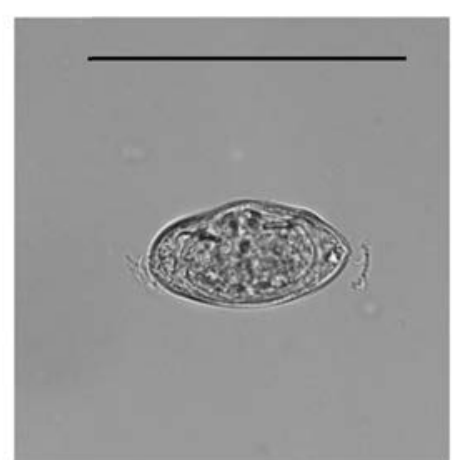

Fig. 5. Some peculiarities of Wardium mackoifusa sp. n. A - crown of rostellar hooks; B - cirri; C-fragment of gravid proglottid; $\mathrm{D}-$ egg after maceration of fixed material in water. Scale bars: A, B $-50 \mu \mathrm{m} ; \mathrm{C}, \mathrm{D}-100 \mu \mathrm{m}$. 
renko et Kontrimavichus, 2004 (hooks 16 - 18 long). However all these species have a latch-like structure in copulatory part of vagina, the specific morphological character of the genus (Bondarenko \& Kontrimavichus, 2004). This feature is absent in W. mackoifusa sp. n.

Only three species of the genus Hymenolepis s.l. have rostellar hooks similar to the hooks of W. mackoifusa sp. n.: Hymenolepis (s.1.). fusus, Hymenolepis (s.1.) neosouthwelli Hughes, 1940 (syn. Hymenolepis fusus Southweell, 1930, Hymenolepis pseudofusa Skrjabin et Matevossian, 1942), Hymenolepis (s.1.) paucispinosum (Labriola et Suriano, 2000) Bondarenko et Kontrimavichus, 2004.

Hymenolepis s.l. fusus (hooks 16 - 18 long) was found in different gulls, $H$. (s.1.) paucispinosum (hooks $12-14$ long) was described from Larus maculipennis (Lichtenstein, 1823) in Argentina. They differ from W. mackoifusa sp. n. by the shape and armament of cirrus and by development of genitalia. Cirrus of $H$. (s.l.) fusus is spindleshaped with small distinct swelling that is densely covered by large spines. Cirrus of $H$. (s.1.) paucispinosum is larger (maximum length 90), it is cylindrical, with small basal enlargement. It is armed with thin long spines. Its narrowed distal end is unarmed. Genital atrium of $H$. (s.1.) paucispinosum is muscular. Male and female genitalia of $H$. (s.l.) fusus and H. s.l. paucispinosum develope simultaneously (Maksimova, 1987; Bondarenko \& Petkevichiute, 1998; Labriola \& Suriano, 2000; Bondarenko \& Kontrimavichus, 2004).

Hymenolepis (s.1.) neosouthwelli (hooks 16 long) was described from a Chroicocephalus brunneicephalus (Jerdon, 1840) (Syn. Larus brunneicephalus Jerdon, 1840) in India. It differs from $W$. mackoifusa sp. n. by shorter handle and bent guard of rostellar hooks and by shorter cirrus sac (judging by the Fig. 291 in Southwell, 1930).

\section{Discussion}

All species listed in the remarks species, except for H. (s.1.) fusus, have not found in the little gull (Larus minutus). Most probably, W. mackoifusa sp. n. was mistakenly identified as $H$. (s.l.) fusus from the little gull. At least all collection specimens of $H$. (s.l.) fusus from the little gull from Ukraine appear to be the new species after revision. Since there is a number of sides of $H$. (s.1.) fusus from other gulls and the slides of W. spasskii from the little gull we could easily distinguish $W$. mackoifusa sp. n. from them.

\section{Acknowledgements}

We are grateful to Yuriy Kuzmin for his useful comments on the text of the manuscript.

\section{References}

Ahern, W. B., SchmidT, G. D. (1976): Parasitic hel- minthes of American avocet Recurvirostra americana: Four new species of the families Hymenolepididae and Acoleidae (Cestoda: Cyclophyllidea). Parasitology, 73: 381 - 398. DOI: $10.1017 / \mathrm{S} 0031182000047053$

BONDARENKO, S. K., KONTRIMAVICHUS, V. L. (2004): On Branchiopodataenia n. g., parasites in gulls, and its typespecies, B. anaticapicirra n. sp. (Cestoda: Hymenolepididae. Syst. Parasitol, 57(2): 119 - 133. DOI: 10.1023/B:SYPA.0000013857.68680.32

BondarenKO, S. K., Kontrimavichus, V. L. (2006): Fundamentals of Cestodology, Vol. 14, Aploparaksidae of wild and domesticated birds. Publ. House Nauka, Moscow, 443 pp. (in Russian)

Bondarenko, S. K., Petkevichiute, R. (1998): On the type species of the genus Wardium - Wardium fryei (Cestoda: Hymenolepididae: Aploparaksinae). Parazitologia, 32(3): 221 - 235 (in Russian).

CoIL, W. H. (1956): Two new hymenolepidid Cestodes from Mexican birds, with observation on Hymenolepis crocethiae Webster, 1947. J. Parasitol, 42 (6): 584 - 587. DOI: $10.2307 / 3274876$

GRUSHCHINSKAJA, I. V. (1978): The cestode and nematode fauna of fish-eating birds at the Kremenchug Reservoir. Problemy Hydrobiologii. Publ. House Naukova dumka, Kyiv, 25 - 29 (in Russian).

LAbriola, J. B., Suriano, D. M. (2000): Wardium paucispinosum sp. n. (Eucestoda: Hymenolepididae), parasite of Larus maculipennis (Aves: Laridae) in Mar del Plata, Argentina; with comments on Wardium semiductilis (Szidat, 1964) comb. n. Folia Parasitologica, 47: 205 210. PMID: 11104148

MACKO, J. K. (1964): On the Cestode Fauna of Laridae from the Migration Roads in Slovakia (ČSSR). Helminthologia, 5(1-4): $53-71$.

MAKSimovA, A. P. (1987) On morphology and developmental cycle of cestode Wardium fusa (Cestoda: Hymenolepididae). Parazitologia, 21(2): 157 - 159 (in Russian). Oshmarin, P. G. (1963): Parasitic worms of mammalian and birds in Primorskiy Kray. Publ. Akademia Nauk SSSR, Moscow, 323 pp. (in Russian).

RYZHIKOV, K. M., RYŠAVÝ, B, KHOKHLOVA, I. G., TOlKaCheVA, L. M., Kornyushin, V. V. (1985): Helminths of Fish-Eating Birds of the Palaearctic region, II Cestoda, Moscow-Prague Publishing 412 pp.

SMOGORZHEVSKAYA L. A. (1976) Helminths of aquatic and marsh birds of the fauna of the Ukraine. Publ. House Naukova dumka, Kyiv, 416 pp. (in Russian).

SMOGORZHEVSKAYA, L. A., ISKOVA, N. I., Kornyushin, V. V., Shalimova, A. N. (1978): The materials to helminthofauna of birds from the Black Sea Biosphere Reserve. In 50 years of Black Sea Biosphere Reserve. Publ. House Naukova dumka, Kyiv, 141 - 152 (in Russian).

Southwell, T. (1930): The fauna of British India including Ceylon and Burma, Cestoda, II, London, 262 pp. 